\title{
Murine strain differences in airway inflammation caused by diesel exhaust particles
}

\author{
Y. Miyabara*, R. Yanagisawa*+, N. Shimojo+§, H. Takano*, H.B. Lim*, T. Ichinose*, M. Sagai*
}

Murine strain differences in airway inflammation caused by diesel exhaust particles. $Y$. Miyabara, R. Yanagisawa, N. Shimojo, H. Takano, H.B. Lim, T. Ichinose, M. Sagai. (OERS Journals Ltd 1998.

ABSTRACT: To elucidate whether immunoglobulin (Ig) $\mathbf{E}$ or IgG are involved in the murine asthma model, we compared the pathogenic features of mice that were high IgG responders $(\mathrm{C} 3 \mathrm{H} / \mathrm{He})$ with mice that were high $\mathrm{IgE}$ responders $(\mathrm{BALB} / \mathrm{c})$ after intratracheal instillation of diesel exhaust particles (DEP) and ovalbumin sensitization.

Both mouse strains received DEP intratracheally once a week for 5 weeks. After the second injection of DEP, ovalbumin and aluminium hydroxide were injected intraperitoneally. After the last DEP administration, the mice were challenged by exposure to an aerosol of ovalbumin.

DEP caused increased IgG1 production and airway hyperresponsiveness after ovalbumin sensitization in $\mathrm{C} 3 \mathrm{H} / \mathrm{He}$ mice, although IgE production did not change in either strain. Furthermore, in $\mathrm{C} 3 \mathrm{H} / \mathrm{He}$ mice, the number of esinophils and goblet cells in the bronchial epithelium, and the expression of interleukin-5 and interleukin-2 were increased by DEP and ovalbumin treatments. In contrast, the pathogenic changes in BALB/c mice were weak, even though the same protocol was used.

In conclusion, murine strain differences in response to air pollutants and allergens seem to be related to antigen-specific immunoglobulin G1 production and cytokine expression in the lungs.

Eur Respir J 1998; 11: 291-298.
*Research Team for Health Effects of Air Pollutants, National Institute for Environmental Studies (NIES), 16-2 Onogawa, Tsukuba, Ibaraki 305, Japan. ${ }^{+}$School of Environmental Science and ${ }^{\S}$ School of Medicine, University of Tsukuba, Tennodai 1-1-1, Tsukuba, Ibaraki 305, Japan

Correspondence: Y. Miyabara

Research Team for Health Effects of Air Pollutants

National Institute for Environmental Studies

16-2 Onogawa

Tsukuba

Ibaraki 305

Japan

Fax: 81298514732

Keywords: Airway hyperresponsiveness, al-lergic airway inflammation, cytokine, diesel exhaust particles, immunoglobulin G1

Received: March 241997

Accepted after revision October 211997
Urban areas have been polluted heavily by nitrogen dioxide $\left(\mathrm{NO}_{2}\right)$ and suspended particulate matters (SPM) [1] The primary source of $\mathrm{NO}_{2}$ and SPM in urban areas is vehicle emissions. The ratio of vehicle emission to total oxides of nitrogen $\left(\mathrm{NO}_{\mathrm{x}}\right)$ exhausts in Tokyo and Osaka in 1990 were $70 \%$ and $56 \%$, respectively [2]. The number of diesel-powered cars has been increasing, and diesel vehicles emit more $\mathrm{NO}_{2}$ and particulates than petrol-engined cars. Therefore, the ratio of diesel exhaust particles (DEP) to SPM is very high in urban air; in Tokyo in 1989 it was at least $40 \%$ [2]. DEP contains elemental carbon nuclei that adsorb a variety of organic compounds and a trace amount of heavy metals. Some of these organic compounds are strong mutagens and carcinogens [3-5]. It has been established that DEP causes lung tumours in a dosedependent manner [6].

It has been shown that the prevalence of allergic rhinitis among schoolchildren is significantly higher in districts polluted by automobile exhaust than in nonpolluted districts [7]. Although, there have been numerous attempts to demonstrate the relationship between $\mathrm{NO}_{2}$ and bronchial asthma, no direct link has been demonstrated experimentally. Furthermore, no experimental study has addressed the relationship between DEP and asthma. A previous report from our laboratory showed that repeated intratracheal instillations of DEP in mice induced chronic airway inflammation with infiltration of eosinophils and lympho- cytes, and airway hyperresponsiveness with hypersecretion of mucus [8].

It is clear in allergic diseases such as asthma that allergen-specific immunoglobulin (Ig) E plays a central role in hypersensitivity reactions, and that the IgE-mediated reactions are followed by chronic inflammation leading to increased airway responsiveness. It has also been shown that DEP has adjuvant effects on IgE production in mice in cases of allergic rhinitis [9]. Intranasal instillation of DEP and antigen induced an increase of antigen-specific IgE antibody in mouse sera [10]. However, some observations suggest the existence of alternative and/or additional pathways of hypersensitivity reactions. Firstly, allergeninduced bronchial hyperreactivity and eosinophilic inflammation occur in IgE and mast cell-deficient mice [11, 12]. Secondly, immediate hypersensitivity and airway hyperresponsiveness were induced by the administration of ovalbumin (OVA)-specific IgE or IgG1, but not IgG2a or IgG3 [13]. We developed a murine asthma model by intratracheal instillation of DEP and OVA, and found that DEP enhanced the production of allergen specific $\operatorname{IgG} 1$, airway inflammation and airway hyperresponsiveness, before it enhanced IgE production [14]. Thus, both IgG and IgE antibodies are involved in allergic airway inflammation and airway hyperresponsiveness in that murine model of asthma. 
To determine which immunoglobulin is more important in allergic asthma, we compared the production of antigen-specific $\operatorname{IgE}$ and $\operatorname{IgG} 1$, airway inflammation, airway hyperresponsiveness, and local cytokine expression between high $\mathrm{IgG}$ responders $(\mathrm{C} 3 \mathrm{H} / \mathrm{He})$ [15] and high $\mathrm{IgE}$ responders (BALB/c) [16] after intratracheal instillation of DEP and OVA sensitization.

\section{Materials and methods}

\section{Animals}

Male $\mathrm{C} 3 \mathrm{H} / \mathrm{He}$ and $\mathrm{BALB} / \mathrm{c}$ mice, aged 8-10 weeks, weighing 21-25 g, were obtained from Japan Clea Co. (Tokyo, Japan). They were fed a commercial stock diet (Japan Clea Co.) and water ad libitium. The mice were housed in an animal facility maintained at $24-26^{\circ} \mathrm{C}$ with $55-75 \%$ humidity and a light/dark cycle of $14 \mathrm{~h} / 10 \mathrm{~h}$. The study adhered to the National Institute of Health guidelines for the use of experimental animals.

\section{Study design}

Both strains of mice were divided into five groups: normal controls (nontreatment group); vehicle-saline; DEPsaline; vehicle-OVA and DEP-OVA. Vehicle or DEP were instilled by the intratracheal route through a polyethylene tube under anaesthesia with $4 \%$ halothane. The vehicle was $50 \mathrm{mM}$ phosphate buffered saline (PBS; pH 7.4) containing $0.05 \%$ Tween 80 . DEP was suspended in the vehicle at a concentration of $250 \mu \mathrm{g} \cdot \mathrm{mL}^{-1}$ and the suspension was sonicated for $5 \mathrm{~min}$ using an ultrasonic disrupter (UD-201; Tomy Seiko, Tokyo, Japan) at 50\% power with ice cooling.

The vehicle and DEP treated groups received $0.1 \mathrm{~mL}$ of the vehicle or DEP suspension once a week for 5 weeks. At $24 \mathrm{~h}$ after the second intratracheal injection of DEP or vehicle, $1 \mathrm{mg}$ of OVA dissolved in $0.5 \mathrm{~mL}$ of a $3 \mathrm{mg} \cdot \mathrm{mL}^{-1}$ suspension of aluminium hydroxide in saline solution was injected intraperitoneally as a sensitization step. At $24 \mathrm{~h}$ after the last DEP administration, these mice were challenged by exposure to an aerosol of $1 \%$ OVA in saline administered through an ultrasonic nebulizer (NE-U07; Omron Co., Tokyo, Japan) in a $2 \mathrm{~L}$ chamber for $15 \mathrm{~min}$. Unsensitized mice were injected with saline instead of OVA-aluminium hydroxide and challenged with aerosolsaline as described above. The animals were killed $24 \mathrm{~h}$ after the challenge with saline or OVA.

\section{Drugs and chemicals}

Acetylcholine (ACh), diethyl ether, thimerosal, phenylmethane sulphonyl fluoride, Tween 20, and Tween 80 were purchased from Nacarai Tesque (Kyoto, Japan). Anti- mouse IgE rat horseradish peroxidase-conjugated streptavidin, bovine serum albumin (BSA), ethylenediamine tetraacetic acid (EDTA), 4-methyl-umbelliferyl- $\beta$-galacto-side and OVA (grade V) were purchased from Sigma Chemical Co., Ltd. (St. Louis, MO, USA). Biotinylated rabbit anti-mouse IgG1 and $\beta$-Dgalactosi- dase-conjugated streptavidin were obtained from Zymed Laboratories (San Francisco, CA, USA). Leupeptin and pepstatin were supplied by Peptide Institute (Osaka, Japan). Halothane was purchased from Hoechst Japan (Tokyo, Japan). PBS (pH 7.4) was obtained from Nissui Pharmaceutical Co., Ltd. (Tokyo, Japan). Diff-Quik was supplied by International Reagents Co., Ltd. (Kobe, Japan). Anti-mouse IgE rat mo-noclonal antibody was purchased from Yamasa Shoyu Co., Ltd. (Chiba, Japan). Shiff's reagent was obtained from Merck (Darmstadt, Germany). All chemicals were of the highest grade available.

\section{Collection of DEP}

A4JB-1-type, light-duty $(2,740 \mathrm{~mL})$, four-cylinder diesel engine (Isuzu Automobile Co., Tokyo, Japan) was connected to an EDYC dynamometer (Meiden-sha, Tokyo, Japan) to regulate driving conditions. The engine was operated using standard diesel fuel at a speed of 1,500 revolutions per minute $(\mathrm{rpm})$ under a load of $10 \mathrm{~kg} \cdot \mathrm{m}^{-1}$. DEP were collected as described previously [17]. Most of the particles were globular in shape. The mean diameter of the particles was $0.4 \mu \mathrm{m}$.

\section{Blood retrieval and analysis}

Mice were anaesthetized with diethyl ether. The chest and abdominal walls were opened, and blood was retrieved by cardiac puncture. Plasma was prepared and frozen at $-80^{\circ} \mathrm{C}$ until assay for OVA-specific IgE and IgG1.

\section{OVA-specific IgE determination}

The titre of OVA-specific IgE antibody was measured by enzyme-linked immunosorbent assay (ELISA) [18]. In brief, microplate wells (Dynatech, Chantilly, VA, USA) were coated with an anti-mouse IgE rat monoclonal antibody at $37^{\circ} \mathrm{C}$ for $3 \mathrm{~h}$, and incubated at $37^{\circ} \mathrm{C}$ for $1 \mathrm{~h}$ with PBS containing $1 \%$ BSA and $0.01 \%$ thimerosal. After washing with PBS containing 0.05\% Tween 20 (PBST), diluted serum samples were added to the wells and incubated overnight at $4^{\circ} \mathrm{C}$. After washing with PBST, biotinylated OVA was added to each well and incubated for $1 \mathrm{~h}$ at room temperature. After washing, wells were incubated for $1 \mathrm{~h}$ at room temperature with $\beta$-Dgalactosidase-conjugated streptavidin. After the final washing, wells were incubated with 4-methylumbelliferyl- $\beta$-galactoside as the enzyme substrate at $37^{\circ} \mathrm{C}$ for $2 \mathrm{~h}$. The enzyme reaction was stopped with $0.1 \mathrm{M}$ glycine- $\mathrm{NaOH}$ buffer solution ( $\mathrm{pH} 10.3)$. The fluorescence intensity was read by a microplate reader (Fluoroskan Flow Laboratories, Costa Mesa, CA, USA). Each plate included a previously screened standard plasma that contained a high titre of anti-OVA antibodies. For standardization, a titre of one was defined as twice the fluorescence of pre-immune plasma (blank). The OVA-specific IgE was calculated using a standard curve made by serial dilution of the standard plasma and dilution factor. Samples with a titre lower than one were considered negative. ELISA antibody titre was expressed as the highest plasma dilution giving a positive reaction. 


\section{OVA-specific IgG1 determination}

OVA-specific IgG1 was measured by ELISA with solid phase antigen. In brief, microplate wells were coated with OVA overnight at $4^{\circ} \mathrm{C}$. Then the plate was incubated at room temperature for $1 \mathrm{~h}$ with $1 \%$ BSA-PBS containing $0.01 \%$ thimerosal. After washing with PBST, diluted serum samples were added to the wells and incubated at room temperature for $1 \mathrm{~h}$. After one more washing with PBST, the plate was incubated at room temperature for $1 \mathrm{~h}$ with biotinylated rabbit anti-mouse IgG1. After another washing, wells were incubated with horseradish peroxidase-conjugated streptavidin at room temperature for $1 \mathrm{~h}$. Then, wells were washed and incubated with $o$-phenylenediamine and hydrogen peroxide $\left(\mathrm{H}_{2} \mathrm{O}_{2}\right)$ in the dark at room temperature for $30 \mathrm{~min}$. The enzyme reaction was stopped with $4 \mathrm{~N}$ sulphuric acid. Absorbance at $490 \mathrm{~nm}$ was read by a microplate reader (Model 3550; Bio-Rad Laboratories, Hercules, CA, USA). Each plate included standard serum that contained a high titre of anti-OVA IgG1 antibodies. OVA-specific IgG1 titres were calculated as above for IgE titres.

\section{Measurement of airway responsiveness}

Pulmonary function was measured by the method of SaRKNES et al. [19], with a minor modification. In brief, each mouse was anaesthetized with pentobarbital sodium $\left(50 \mathrm{mg} \cdot \mathrm{kg}^{-1}, i . p\right.$.), and a tracheostomy was performed with an 18-gauge cannula. Each mouse was mechanically ventilated with a rodent respirator (Model 683; Harvard Apparatus, South Natick, MA, USA) in a plethysmograph box with a pneumotachometer (BUXCO Electronics, Inc., Sharon, CT, USA) at a constant tidal volume $(0.3 \mathrm{~mL})$ and at a respiratory frequency of 120 breaths $\cdot \mathrm{min}^{-1}$. Spontaneous respiration was inhibited by pancuronium bromide (1 $\left.\mathrm{mg} \cdot \mathrm{kg}^{-1}, i . m.\right)$. Continuous measurements of endotracheal pressure, flow, respiratory resistance $(R \mathrm{rs})$, and dynamic lung compliance $(C$ dyn $)$ were recorded on a six-chan- nel recorder (BUXCO Electronics, Inc.). A $4 \mathrm{~s}$ average of $R \mathrm{rs}$ and $C$ dyn was also recorded. An ACh challenge was performed with ACh solution $\left(0.313-10 \mathrm{mg} \cdot \mathrm{mL}^{-1}\right)$ inhaled for $2 \mathrm{~min}$. The solution was aerosolized by an ultrasonic nebulizer (NE-U07; Omron Co.), which generates aerosol particles of approximately $5 \mu \mathrm{m}$ in diameter.

Histological evaluation of eosinophils, lymphocytes, neutrophils and goblet cells in the lung

After exsanguination, the lungs were fixed by intratracheal instillation with $10 \%$ neutral phosphate-buffered formalin at a pressure of $20 \mathrm{cmH}_{2} \mathrm{O}$ for at least $72 \mathrm{~h}$. Slices (2-3 mm thick) of all pulmonary lobes were embedded in paraffin. Sections (3 $\mu \mathrm{m}$ thick) were prepared and stained with Diff-Quik to quantify the number of infiltrated eosinophils, lymphocytes and neutrophils. The length of the basement membrane of all airways in each specimen was measured by video micrometer (VM-30; Olympus, Tokyo, Japan). The numbers of eosinophils, lymphocytes and neutrophils under bronchial epithelium in each sample were counted with a micrometer (AX80; Olympus) under oil immersion. Results were expressed as the number of inflammatory cells per millimetre of basement membrane. To quantify goblet cells, the sections were stained with periodic acid Schiff (PAS). The number of goblet cells that stained red in the bronchial epithelium were counted by micrometer. Results were expressed as the number of goblet cells per millimetre of basement membrane.

\section{Quantification of cytokine protein levels in lung tissue supernatants}

Murine lungs were removed after exsanguination, frozen in liquid nitrogen and stored at $-80^{\circ} \mathrm{C}$ until assay. Each lung was homogenized with $10 \mathrm{mM}$ potassium phosphate buffer (pH 7.4) containing $0.1 \mathrm{mM}$ EDTA, $0.1 \mathrm{mM}$ phenylmethane sulphonyl fluoride, $1 \mu \mathrm{M}$ pepstatin, and 2 $\mu \mathrm{M}$ leupeptin. The homogenate was then centrifuged at $105,000 \times \mathrm{g}$ for $1 \mathrm{~h}$ at $4^{\circ} \mathrm{C}$. The supernatant was stored at $-80^{\circ} \mathrm{C}$.

ELISAs for interleukin-5 (IL-5), granulocyte-macrophage colony stimulating factor (GM-CSF), and interleukin-2 (IL-2) were conducted using matching antibody pairs (Endogen, Cambridge, MA). The antibody pairs for detection of IL-5, GM-CSF and IL-2 were TRFK5 and TRFK4, MP1-22E9 and MP1-31G6 and S4B6 and H5 4.1.1, respectively. The ELISA for interleukin-4 (IL-4) was conducted using matching antibody pairs (Amersham, Buckinghamshire, UK) according to the manufacturer's instructions. The second antibodies were conjugated to horseradish peroxidase. Subtractive readings of $550 \mathrm{~nm}$ from the readings at $450 \mathrm{~nm}$ were converted to picograms per millilitre using values obtained from standard curves generated with varying concentrations of recombinant IL-5, GM-CSF, IL-2 and IL-4. The detection limits of each assay were $5,5,3$ and $5 \mathrm{pg} \cdot \mathrm{mL}^{-1}$, respectively.

\section{Statistical analysis}

Data are reported as mean \pm SEM Differences in the numbers of infiltrated inflammatory cells and goblet cells, airway hyperresponsiveness, cytokine protein levels and immunoglobulin titres among groups were determined using analysis of variance (Statview; Abacus Concepts, Inc., Berkeley, CA, USA). If differences among groups were significant $(p<0.05)$, Fisher's protected least significant difference test or Scheffe's F-test were used to distinguish between pairs of groups.

\section{Results}

\section{Airway inflammation}

The inflammatory cellular profiles of five groups in $\mathrm{C} 3 \mathrm{H} / \mathrm{He}$ and $\mathrm{BALB} / \mathrm{c}$ mice are shown in table 1.

In $\mathrm{C} 3 \mathrm{H} / \mathrm{He}$ mice, OVA sensitization (vehicle-OVA) caused eosinophilic infiltration, and the combined DEP and OVA treatment (DEP-OVA) led to a marked and significant infiltration under bronchial epithelia. The number of eosinophils in the DEP-OVA group were 13 and seven times higher than that in the vehicle-saline $(\mathrm{p}<0.01)$ 
Table 1. - Effects of diesel exhaust particles (DEP) and/or ovalbumin (OVA) administration on inflammatory cell counts of respiratory tract in $\mathrm{C} 3 \mathrm{H} / \mathrm{He}$ and $\mathrm{BALB} / \mathrm{c}$ mice

\begin{tabular}{|c|c|c|c|c|c|c|}
\hline \multirow[t]{2}{*}{ Group } & \multicolumn{2}{|c|}{$\begin{array}{l}\text { Eosinophil } \\
\text { counts } \cdot m^{-1}\end{array}$} & \multicolumn{2}{|c|}{$\begin{array}{l}\text { Neutrophils } \\
\text { counts } \cdot \mathrm{mm}^{-1}\end{array}$} & \multicolumn{2}{|c|}{$\begin{array}{l}\text { Lymphocytes } \\
\text { counts } \cdot \mathrm{mm}^{-1}\end{array}$} \\
\hline & $\mathrm{C} 3 \mathrm{H} / \mathrm{He}$ & BALB/c & $\mathrm{C} 3 \mathrm{H} / \mathrm{He}$ & BALB/c & $\mathrm{C} 3 \mathrm{H} / \mathrm{He}$ & BALB/c \\
\hline Normal control & $0.003 \pm 0.003$ & $0.005 \pm 0.005$ & $0.015 \pm 0.007$ & $0.028 \pm 0.007$ & $0.477 \pm 0.063$ & $0.467 \pm 0.081$ \\
\hline Vehicle-saline & $0.114 \pm 0.046$ & $0.003 \pm 0.003$ & $0.030 \pm 0.009$ & $0.032 \pm 0.022$ & $0.592 \pm 0.129$ & $0.418 \pm 0.127$ \\
\hline DEP-saline & $0.033 \pm 0.011$ & $0.013 \pm 0.003$ & $0.040 \pm 0.007$ & $0.026 \pm 0.023$ & $0.510 \pm 0.096$ & $0.365 \pm 0.106$ \\
\hline Vehicle-OVA & $0.215 \pm 0.066$ & $0.110 \pm 0.028 *$ & $0.069 \pm 0.014 *$ & $0.052 \pm 0.016$ & $0.560 \pm 0.184$ & $0.621 \pm 0.135$ \\
\hline DEP-OVA & $1.450 \pm 0.211^{* *}$ & $0.314 \pm 0.063 * *$ & $0.066 \pm 0.034 *$ & $0.058 \pm 0.009$ & $1.078 \pm 0.123 *$ & $0.959 \pm 0.102 *$ \\
\hline
\end{tabular}

Animals $(n=5)$ received intratracheal instillation of vehicle or DEP for 5 weeks with or without OVA sensitization. Lungs were removed and fixed $24 \mathrm{~h}$ after the OVA challenge. Sections were stained with Diff-Quik for measurement of inflammatory cells around the airways. Results are expressed as number of cells per length of basement membrane of airways. Data are presented as mean \pm SEM *: $\mathrm{p}<0.05 ; * *: \mathrm{p}<0.01$, compared to vehicle-saline group (Student's t-test or Cochran-Cox test).

and the vehicle-OVA $(\mathrm{p}<0.01)$ groups, respectively. There was a small increase in eosinophils in the nonsensitized groups (vehicle-saline and DEP-saline) above the normal control group $(\mathrm{p}<0.05)$. The numbers of infiltrated neutrophils in the DEP-OVA group were only 1.0-1.6 times higher than that in the vehicle-OVA and DEP-saline groups. A twofold increase in infiltrated lymphocytes was observed in the DEP-OVA group as compared to the vehicle-saline or vehicle-OVA groups $(\mathrm{p}<0.05)$. Thus, the inflammation induced in $\mathrm{C} 3 \mathrm{H} / \mathrm{He}$ mice by DEP and OVA was characterized by a marked infiltration of eosinophils.

In BALB/c mice, OVA sensitization (vehicle-OVA and DEP-OVA) caused eosinophilic infiltration, but it was not as marked as that of the $\mathrm{C} 3 \mathrm{H} / \mathrm{He}$ mice. The number of eosinophils in the DEP-OVA group was three times higher than that of the vehicle-OVA group $(p<0.05)$. The combined DEP and OVA instillation induced a less than 2.2 times elevation of infiltrated neutrophils as compared with either the vehicle-OVA or DEP-saline groups. A 1.5 fold increment in infiltrated lymphocytes in the DEPOVA group was observed compared with the vehicle-OVA group $(\mathrm{p}<0.05)$.

Infiltration by inflammatory cells in the DEP-OVA groups of both strains were characterized by an increase of eosinophils. The inflammatory cells of the normal control groups were approximately equal for both strains. However, the number of eosinophils in $\mathrm{C} 3 \mathrm{H} / \mathrm{He}$ mice compared with BALB/c mice for vehicle-saline, DEPsaline, vehicle-OVA, and DEP-OVA groups were 38, two, three and five times higher, respectively.

\section{Mucus hypersecretion}

The lung specimen was stained with PAS to estimate the hypersecretion of mucus in the airway. The numbers of goblet cells per length of basement membrane of the airways in $\mathrm{C} 3 \mathrm{H} / \mathrm{He}$ and $\mathrm{BALB} / \mathrm{c}$ mice are shown in figure 1.

In the $\mathrm{C} 3 \mathrm{H} / \mathrm{He}$ mice groups, a marked number of goblet cells were observed in the DEP-OVA group. The number of goblet cells in the DEP-OVA group was 27 times higher than that of the vehicle-saline group $(p<0.05)$ and four times higher than that of the vehicle-OVA $(p<0.05)$ groups. The numbers of goblet cells in the nonsensitized groups (vehicle-saline and DEP-saline) were small.

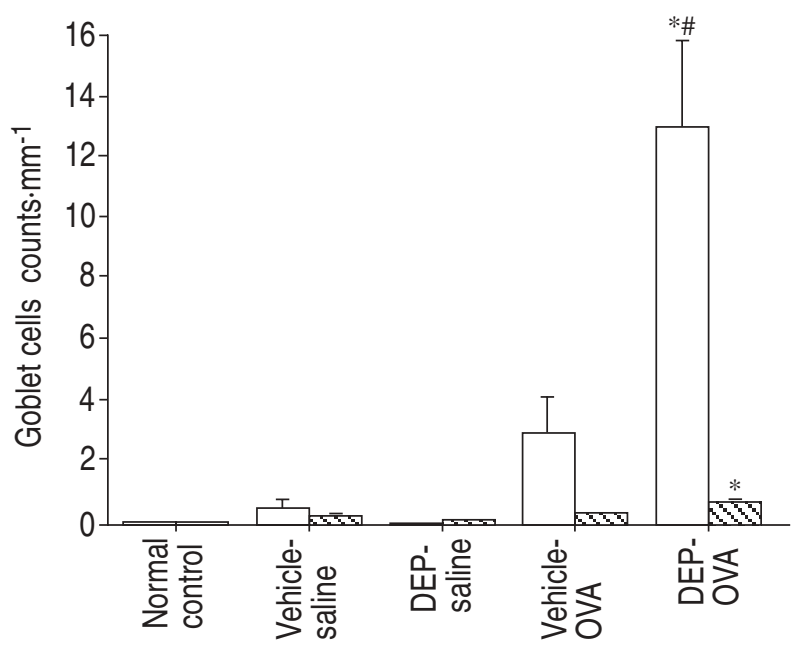

Fig. 1. - Effects of diesel exhaust particles (DEP) and/or ovalbumin (OVA) administration on increase of goblet cells in $\mathrm{C} 3 \mathrm{H} / \mathrm{He}(\square)$ and $\mathrm{BALB} / \mathrm{c}$ mice ( $\mathrm{O}$ ). Two strains of mice were intratracheally instilled with vehicle or DEP once a week for 5 weeks with or without OVA sensitization. Lungs were removed and fixed $24 \mathrm{~h}$ after saline or OVA challenge. Sections were stained with peroxide acid Schiff for measurement of goblet cells under bronchial epithelia. Results are expressed as mean \pm SEM $(n=5)$. *: $p<0.05$ versus vehicle saline group; ${ }^{\#}: \mathrm{p}<0.05$ versus vehicle OVA group (Fisher's protected least significance difference test or Scheffe's F-test).

In BALB/c mice, a small number of goblet cells were observed in the DEP-OVA group. The number of goblet cells in the DEP-OVA group was 3.3 times higher than that in the vehicle-saline group $(\mathrm{p}<0.05)$ and 1.6 times higher than that in the vehicle-OVA group $(\mathrm{p}=\mathrm{NS})$. The numbers of goblet cells were small in the nonsensitized groups.

The combined instillation of DEP and OVA increased the number of goblet cells in both strains, but the increment in BALB/c mice was small compared with that in the $\mathrm{C} 3 \mathrm{H} / \mathrm{He}$ mice. The number of goblet cells in the DEPOVA group of the $\mathrm{C} 3 \mathrm{H} / \mathrm{He}$ mice was 17.5 times higher than that of the $\mathrm{BALB} / \mathrm{c}$ mice.

\section{Airway hyperresponsiveness}

We measured the $R \mathrm{rs}$ of $\mathrm{C} 3 \mathrm{H} / \mathrm{He}$ and $\mathrm{BALB} / \mathrm{c}$ mice upon inhalation of ACh to compare the effects of DEP and/or OVA on airway hyperresponsiveness. The increase of $R \mathrm{rs}$ in both mice groups is shown in figure 2 . In $\mathrm{C} 3 \mathrm{H} /$ 


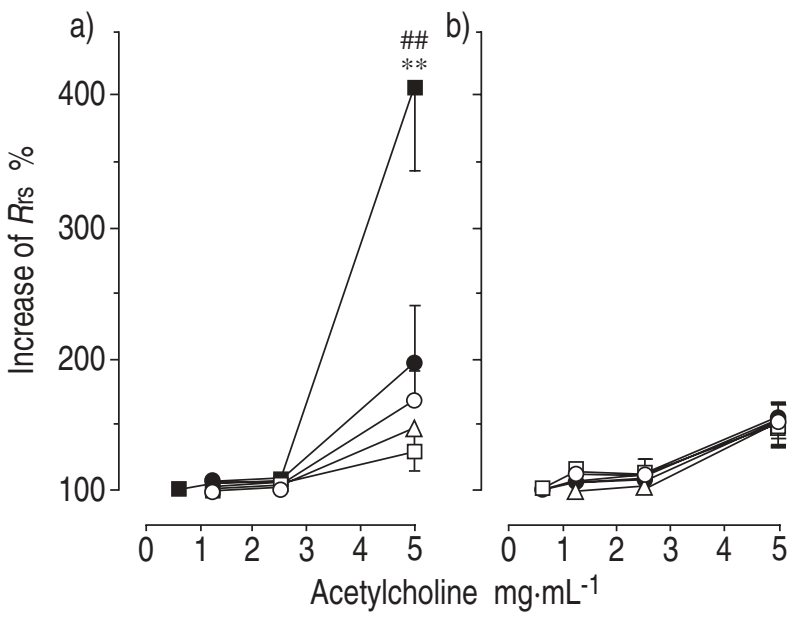

Fig. 2. - Effects of DEP and/or OVA administration on airway responsiveness (airway resistance $(R \mathrm{rs})$ ) to acetylcholine in a) $\mathrm{C} 3 \mathrm{H} / \mathrm{He}$ and b) $\mathrm{BALB} / \mathrm{c}$ mice. Mice were intratracheally instilled with vehicle or DEP once a week for 5 weeks with or without OVA sensitization. Rrs to acetylcholine was measured $24 \mathrm{~h}$ after saline or OVA challenge. Results are expressed as mean \pm SEM $(n=7-8)$. **: $\mathrm{p}<0.01$, compared to vehiclesaline group; \#\#. $\mathrm{p}<0.01$, versus vehicle-OVA group (Fisher's least significant difference test or Scheffe's F-test). $-\mathrm{O}-$ : normal control; $-\triangle-$ : vehicle-saline; ——: DEP-saline; —-—: vehicle-OVA; ———: DEPOVA. For definitions see legend to figure 1.

He mice, $R$ rs was significantly higher only in the DEPOVA group compared with the other four groups $(\mathrm{p}<0.05$ versus each other group). The provocative concentration of ACh causing a $50 \%$ increase in $R \mathrm{rs}(\mathrm{PC} 150)$ in the DEP-OVA group was significantly lower than in the other four groups (PC150 $3.1 \mathrm{mg} \cdot \mathrm{mL}^{-1}$ versus $5.9-8.7 \mathrm{mg} \cdot \mathrm{mL}^{-1}$, $\mathrm{p}<0.05)$. However, there were no significant differences in the increase of $R$ rs among the BALB/c mice groups. The averages of $\mathrm{PC} 150$ in $\mathrm{BALB} / \mathrm{c}$ mice groups were 4.5-6.9 $\mathrm{mg} \cdot \mathrm{mL}^{-1}$ of $\mathrm{ACh}$. There were no significant differences between the normal control $\mathrm{C} 3 \mathrm{H} / \mathrm{He}$ and $\mathrm{BALB} / \mathrm{c}$ mice (PC150 5.9-6.5 mg. $\mathrm{mL}^{-1}$ ).

\section{Antigen-specific IgE and IgG1 production}

OVA-specific IgE and IgG1 in both $\mathrm{C} 3 \mathrm{H} / \mathrm{He}$ and $\mathrm{BALB} / \mathrm{c}$ mice were measured to examine the involvement of these immunoglobulins in allergic asthma, and whether DEP had adjuvant activity on antigen-specific immunoglobulin production after intratracheal instillation of OVA. The titres of OVA-specific IgE were not significantly increased by antigen challenge with or without DEP instillation in either strain, despite manifestations of airway inflammation, mucus hypersecretion and airway hyperresponsiveness. Most values were below the detection limits $(<10$ titre $)$ in both strains of mice.

The titres of OVA-specific IgG1 in the serum of both $\mathrm{C} 3 \mathrm{H} / \mathrm{He}$ and $\mathrm{BALB} / \mathrm{c}$ mice are shown in figure 3 .

OVA-specific IgG1 was significantly elevated by OVA sensitization in both groups of mice. In $\mathrm{C} 3 \mathrm{H} / \mathrm{He}$ mice, the average concentration of IgG1 in the DEP-OVA group was 2.6 times higher than that in the vehicle-OVA group $(\mathrm{p}<0.05)$. However, there was no significant difference between the vehicle-OVA and DEP-OVA groups in BALB/ $\mathrm{c}$ mice. When $\mathrm{C} 3 \mathrm{H} / \mathrm{He}$ and $\mathrm{BALB} / \mathrm{c}$ mice were compared, the titres of IgG1 in the vehicle-OVA and DEP-OVA groups of $\mathrm{C} 3 \mathrm{H} / \mathrm{He}$ mice were 11 and 28 times higher than

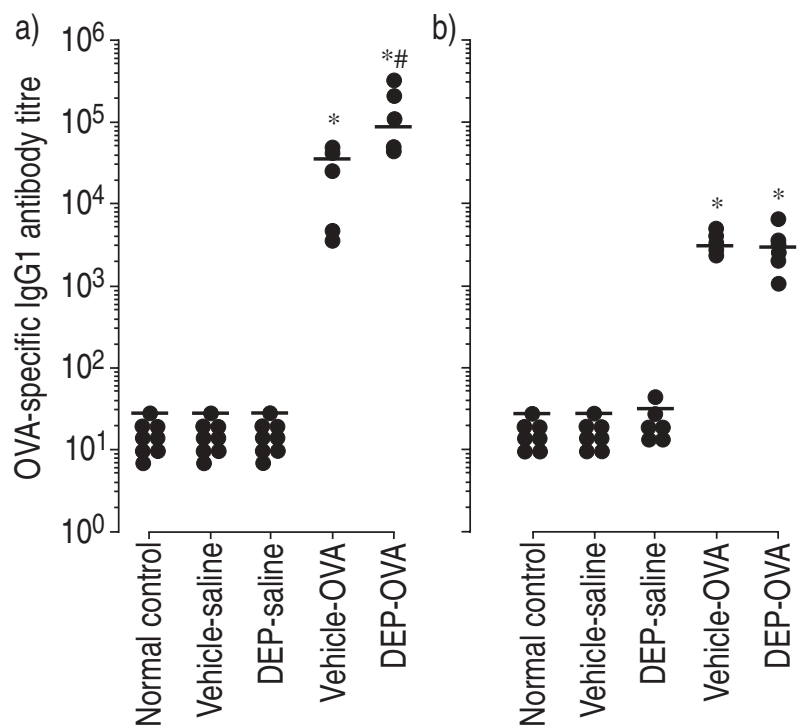

Fig. 3. - Effects of DEP and/or OVA administration on OVA-specific immunoglobulin $\mathrm{G} 1$ (IgG1) antibody productions in a) $\mathrm{C} 3 \mathrm{H} / \mathrm{He}$ and b) BALB/c mice. The mice were intratracheally instilled with vehicle or DEP once a week for 5 weeks with or without OVA sensitization. Plasma samples were retrieved $24 \mathrm{~h}$ after saline or OVA challenge. OVA-specific IgG1 was analyzed using enzyme-linked immunosorbent assay (ELISA) (see text). Results are expressed as individual data. The horizontal bars are the means $(n=7-8)$. *: $\mathrm{p}<0.05$, compared to vehicle-saline group; \#: $\mathrm{p}<0.05$, compared to vehicle-OVA group (Fisher's protected least significant difference test or Scheffe's F-test). For definitions see legend to figure 1.

those of BALB/c mice, respectively. The titres of IgG1 in both vehicle-saline and DEP-saline groups were very low ( $<27$ titres).

\section{Local cytokine expression}

To explore what kinds of cytokines are involved in the enhancing effects of DEP on antigen-induced airway inflammation, mucus hypersecretion and airway hyperresponsiveness, we quantified protein levels of IL-5, GMCSF, IL-2, and IL-4 in the lung supernatants (fig. 4).

The amount of IL-5 increased dramatically in the DEP-OVA and vehicle-OVA groups of $\mathrm{C} 3 \mathrm{H} / \mathrm{He}$ mice, and these increases were 34 and 26 fold greater than the vehicle-saline group, respectively $(\mathrm{p}<0.0001)$. The amount of IL-5 in the normal control group of $\mathrm{C} 3 \mathrm{H} / \mathrm{He}$ mice was three times lower than that of BALB/c mice. However, the IL-5 levels in BALB/c mice did not significantly increase after antigen challenge in the presence or absence of DEP.

GM-CSF in the DEP-OVA and vehicle-OVA groups were significantly greater in $\mathrm{C} 3 \mathrm{H} / \mathrm{He}$ and $\mathrm{BALB} / \mathrm{c}$ mice than in the vehicle-saline group $(\mathrm{p}<0.01)$, but the increases were only 1.3 to 1.7 fold, respectively. There was no significant difference between the vehicle-OVA and DEPOVA groups in either strain. The amount of GM-CSF in $\mathrm{C} 3 \mathrm{H} / \mathrm{He}$ mice was 3.9 to 5.2 fold higher than in $\mathrm{BALB} / \mathrm{c}$ mice.

IL-2 in the DEP-OVA and vehicle-OVA groups of $\mathrm{C} 3 \mathrm{H} /$ He mice showed 17 and 29 fold increases over the vehicle-saline group, respectively $(\mathrm{p}<0.0001)$. However, antigen challenge did not affect IL-2 levels in BALB/c mice with or without DEP treatment. No meaningful differences in IL-4 were observed among mouse strains. 

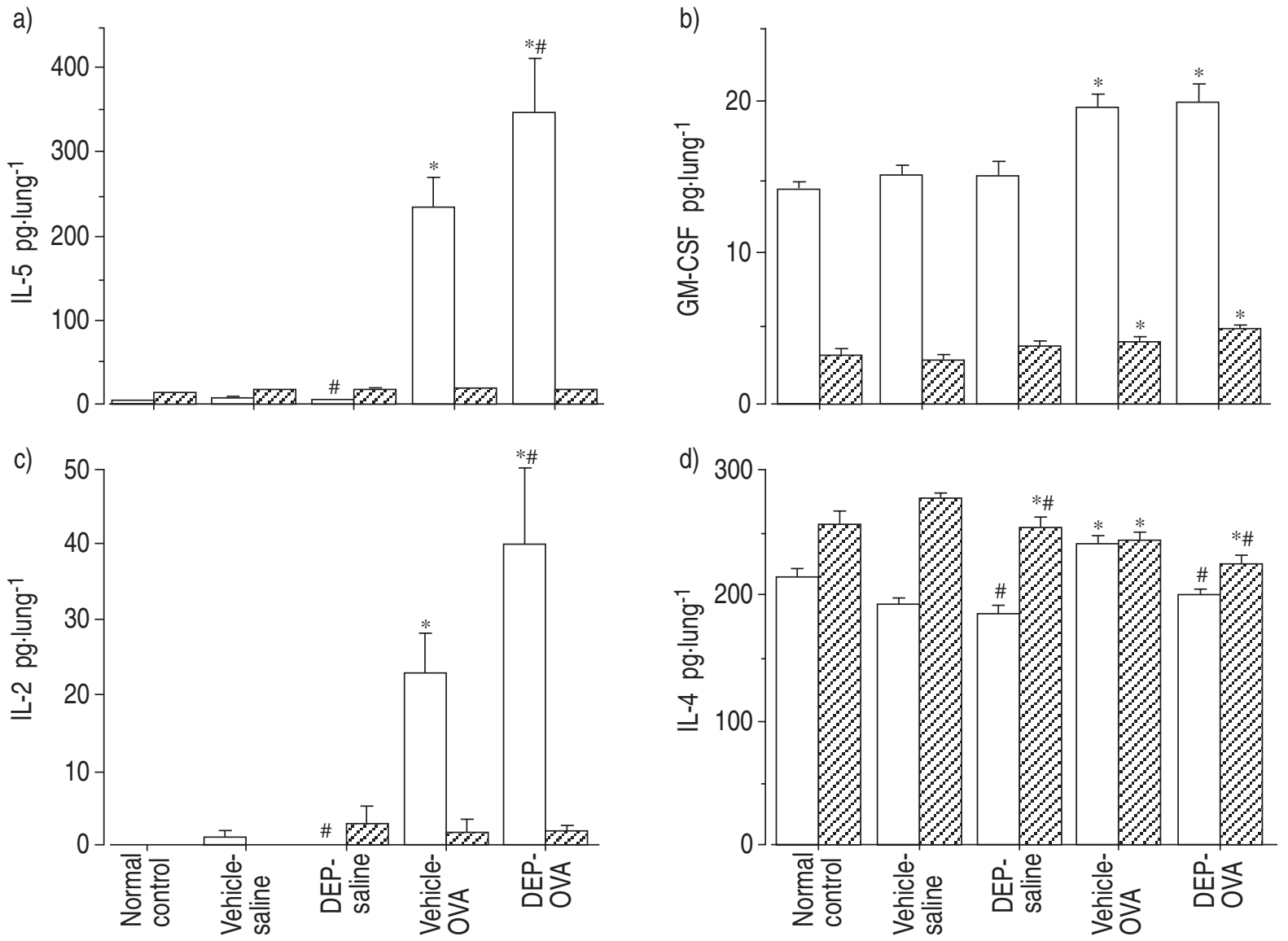

Fig. 4. - Effects of DEP and/or OVA administration on local cytokine expressions in C3H/He ( $\square$ ) and BALB/c ( 22 ) mice. The mice were intratracheally instilled with vehicle or DEP once a week for 5 weeks with or without OVA sensitization. Lungs were removed $24 \mathrm{~h}$ after saline or OVA challenge and frozen until use. Protein levels of four cytokines in lung tissue supernatants were analyzed using enzyme-linked immunosorbent assay (ELISA) (see text). Results are expressed as mean \pm SEM $(n=7-8)$. *: $\mathrm{p}<0.05$, compared to vehicle-saline group; ${ }^{\#}$ : $\mathrm{p}<0.05$, compared to vehicle-OVA group (Fisher's protected least significant difference test or Scheffe's F-test). For definitions, see legend to figure 1.

\section{Discussion}

In the present study, we have demonstrated that airway inflammation with a marked infiltration of eosinophils was induced by the DEP administration with antigen challenge in both $\mathrm{C} 3 \mathrm{H} / \mathrm{He}$ and $\mathrm{BALB} / \mathrm{c}$ mice. The recruitment of eosinophils was accompanied by a hyperplasia of goblet cells in bronchial epithelium as a maker of mucus hypersecretion. Eosinophils and goblet cells were more induced in $\mathrm{C} 3 \mathrm{H} / \mathrm{He}$ mice than in $\mathrm{BALB} / \mathrm{c}$ mice after the DEP and OVA treatment. Airway hyperresponsiveness, IL-5 and IL-2 expressions were enhanced by the DEP administration with OVA challenge in $\mathrm{C} 3 \mathrm{H} / \mathrm{He}$ mice, but not in BALB/c mice. The combination of intratracheal administration of DEP and single antigen challenge by aerosol inhalation induced a significant increase of antigen-specific IgG1 in $\mathrm{C} 3 \mathrm{H} / \mathrm{He}$ mice, but not of antigenspecific IgE in either mouse strain. Thus, the production of IgG1 varied along with the infiltration of eosinophils, airway hyperresponsiveness (PC150) and hyperplasia of goblet cells, but not IgE. However, after the intratracheal administration of DEP and three times of OVA challenge every other day, the antigen-specific antibodies of both $\mathrm{IgE}$ and $\mathrm{IgG} 1$ isotypes were remarkably increased even in $\mathrm{BALB} / \mathrm{c}$ mice, and airway hyperresponsiveness, marked infiltration of eosinophils and lymphocytes, hyperplasia of goblet cells were also observed (data not shown). These results indicate that DEP had an adjuvant effect on OVAspecific IgG production in not only high $\mathrm{IgG}$ responders $(\mathrm{C} 3 \mathrm{H} / \mathrm{He})$ but also high $\mathrm{IgE}$ responders (BALB/c) and that the former is more sensitive to the administration of DEP with OVA than the latter.

Inbred strains of mice have been shown to vary in their ability to produce immunoglobulins. These inbred mice are classified into six $\mathrm{H}-2$ haplotypes, $\mathrm{H}-2^{\mathrm{a}}, \mathrm{H} 2^{\mathrm{b}}, \mathrm{H}-2^{\mathrm{d}}$, $\mathrm{H}-2^{\mathrm{k}}, \mathrm{H}-2^{\mathrm{q}}$, and $\mathrm{H}-2^{\mathrm{s}}$. It has been reported that the $\mathrm{H}-2^{\mathrm{k}}$ haplotype strain shows higher IgG responsiveness to ovalbumin than $\mathrm{H}-2^{\mathrm{b}}$ and $\mathrm{H}-2^{\mathrm{d}}$ strains [15]. In the present study, $\mathrm{C} 3 \mathrm{H} / \mathrm{He}$ mice $\left(\mathrm{H}-2^{\mathrm{k}}\right)$ were more sensitive to OVA than $\mathrm{BALB} / \mathrm{c}\left(\mathrm{H}-2^{\mathrm{d}}\right)$ mice. The titre of $\mathrm{IgG} 1$ in the serum of $\mathrm{C} 3 \mathrm{H} / \mathrm{He}$ mice was 28 times higher than that of BALB/ c mice after the same DEP and OVA treatments. The production of IgG1 was accompanied by recruitment of eosinophils and an increase of goblet cells in bronchial epithelium. This may indicate that genetic factors, such as the H-2 haplotype, are important to the expression of asthmatic features in mice as well as humans.

It has been reported that intranasal DEP administration with antigen demonstrated adjuvant activity for $\operatorname{IgE}$ production in mice [10]. Although IgE is an important component of many allergic reactions, there are some reports which suggest the existence of alternative and/or 
additional pathways of hypersensitivity reactions with IgG prduction in mice [11-14]. Judging from these reports and the present results, DEP with antigen may be able to induce allergic airway inflammation and hyperresponsiveness not with IgE antibody production but with IgG antibody production. It seems that IgG antibody is more important than IgE in murine asthma model, and antigen-specific $\operatorname{IgE}$ and $\mathrm{IgG}$ production is altered by the administration route of allergen. In humans, late asthmatic reactions to an inhaled allergen challenge are associated with IgG1 rather than IgE antibody [20]. Significantly elevated levels of $\operatorname{IgE}$ and $\operatorname{IgG}$ antibodies to inhaled allergens have been detected in children with asthma, and in adults with allergic asthma [21]. IgG antibody as well as $\mathrm{IgE}$ antibody may be involved in allergic bronchial asthma.

Allergic asthma is often associated with activation of IL-4, IL-5, and the GM-CSF gene cluster. Significant associations have been observed between the numbers of cells expressing mRNA for IL-4, IL-5, and GM-CSF and air flow restriction, bronchial hyperresponsiveness, and asthma score [22]. A recent report concerning IL-5-deficient mice supports the concept that IL-5 and eosinophils are central mediators in the pathogenesis of allergic lung diseases [23]. Another study with IL-4-deficient mice implied a significant role for IL-4 in antigen-induced eosinophilic airway inflammation and bronchial responsiveness [12, 24]. GAVET et al. [25] have recently provided the first direct evidence that antigen-induced airway in-flammation and hyperresponsiveness are associated with increases in protein levels of IL-4 and IL-5 in murine BAL supernatants.

In the present study, airway inflammation (eosinophils), airway hyperresponsiveness (PC150), hypersecretion of mucus (goblet cell), IgG1, IL-5, and IL-2 in lung tissue were increased after DEP administration and antigen challenge. These results show that IL-5 and IL-2 are important cytokines in distinguishing strain differences and mechanisms of airway inflammation and hyperresponsiveness. IL-5 acts in the lung to recruit, activate, and prolong the life of eosinophils. Our results agree with previous reports showing that the combined administration of DEP and OVA induced eosinophilic infiltration and IL-5 production in ICR mice [14]. IL-2 causes lymphocyte activation and proliferation and affects the regulation of immunoglobulin production and lymphokine expression related to the activation of other cells. It has been reported that IL-2 administration induced OVA-specific IgG production and airway inflammation [26]. In addition, T-cells from eosinophilic patients produce IL5 after IL-2 stimulation [27]. It seems that the elevated levels of IL-2 in the present experiment play a role in lymphocyte activation and induce the OVA-specific IgG production and cytokine expression. Furthermore, the relatively high level dose of GM-CSF in $\mathrm{C} 3 \mathrm{H} / \mathrm{He}$ mice may enhance the infiltration and activation of inflammatory cells. Although the protein level of IL- 4 did not increase in our model, it may be related to the production of $\mathrm{IgG} 1$ and IgE. The IL-4 IgG1 dose-response curve was bimodal, and IgG1 can be induced by normal levels of IL-4; the response of IgE is directly dependent on a high concentration of IL-4. The amount of IL-4 needed for optimal $\operatorname{IgE}$ secretion is 100 fold higher than that needed for the first peak of IgG1 production [28]. In our study, the con- centration of IL-4 seems to correspond to the first peak, resulting in high levels of IgG1 but not IgE. Furthermore, it was reported that allergen-specific IgG1 antibodies in patient sera contributed to antigen-specific eosinophilic degranulation via Fc $\gamma$ RII on the eosinophil surface. IgG1 with antigen is a strong agonist for eosinophilic degranulation in vitro $[29,30]$. The resulting cytokine expression induces IgG1 production and eosinophil activation, inducing airway inflammation with epithelial damage and airway hyperresponsiveness by degranulation of eosinophils.

Thus, manifestations of asthma-like features in our murine model were well explained with the cytokine expression in the lungs. These strain differences may be related to IL-5 and IL-2 gene expression. In particular, IL-5 positive lymphocytes have been observed in the bronchial mucosa of $\mathrm{C} 3 \mathrm{H} / \mathrm{He}$ mouse by immunohistochemistry (unpublished data). Therefore, the cytokine synthesis and/or release, and its mRNA expression patterns of individual cells in vivo should be investigated in future. It will clarify the mechanism of allergic asthma and human individual variations.

\section{References}

1. Ando M, Katagiri K, Tamura K, et al. Indoor and outdoor air pollution in Tokyo and Bejing supercities. Atmos Environ 1996; 30: 695-702.

2. Sagai M, Ichinose T. Experimental study on onset of asthma like symptoms by diesel exhaust particles (DEP). J Japan Soc Air Pollut 1995; 30: 81-93.

3. Scuetzle D, Lewtas J. Bioassay-directed chemical analysis in environmental research. Anal Chem 1986; 58: 1060A1070A.

4. Draper WM. Quantification of nitro and dinitropolycyclic aromatic hydrocarbons in diesel exhaust particulate matter. Chemosphere 1986; 15: 437-447.

5. Mauderly JL, Jones RK, Griffith WG, Henderson RF, McClellan RO. Diesel exhaust is a pulmonary carcinogen in rats exposed chronically by inhalation. Fundam Appl Toxicol 1987; 9: 208-221.

6. Ichinose T, Yajima Y, Nagashima M, Takenoshita S, Nagamachi Y, Sagai M. Lung carcinogenesis and formation of 8-hydroxy-deoxyguanosine in mice by diesel exhaust particles. Carcinogenesis 1997; 18: 185-192.

7. Kaneko S, Shimada K, Hirouchi H, et al. Nasal allergy and air pollution. Oto-Rhino-Laryngology Tokyo 1980; 23: 270-279.

8. Sagai M, Furuyama A, Ichinose T. Biological effects of diesel exhaust particles (DEP). III. Pathogenesis of asthma like symptoms in mice. Free Radic Biol Med 1996; 21: 199-209.

9. Muranaka M, Suzuki S, Koizumi K, Takafuji S, Miyamoto T, Tokiwa H. Adjuvant activity of diesel-exhaust particles for the production of $\mathrm{IgE}$ antibody in mice. $J$ Allergy Clin Immunol 1986; 77: 616-621.

10. Takafuji S, Suzuki S, Koizumi K, et al. Diesel-exhaust particulates inoculated by the intranasal route have an adjuvant activity for $\mathrm{IgE}$ production in mice. $J$ Allergy Clin Immunol 1987; 79: 639-645.

11. Mehlhop PD, Rijn M, Goldberg AB, et al. Allergen-induced bronchial hyperreactivity and eosinophilic inflammation occur in the absence of $\operatorname{IgE}$ in a mouse model of asthma. Proc Natl Acad Sci USA 1997; 94: 1344-1349.

12. Brusselle GG, Kips JC, Tavernier JH, et al. Attenuation 
of allergic airway inflammation in IL-4 deficient mice. Clin Exp Allergy 1994; 24: 73-80.

13. Oshiba A, Hamelmann E, Takeda K, et al. Passive transfer of immediate hypersensitivity and airway hyperresponsiveness by allergen-specific immunoglobulin (Ig) E and IgG1 in mice. J Clin Invest 1996; 97: 1398-1408.

14. Takano H, Yoshikawa T, Ichinose T, Miyabara Y, Imaoka $K$, Sagai M. Diesel exhaust particles enhance antigen-induced airway inflammation and local cytokine expressions in mice. Am J Respir Crit Care Med 1997; 156: $36-42$.

15. Takeyoshi M, Inoue T. H-2 haplotype and sex-related differences in $\mathrm{IgG}$ response to ovalbumin in mice. Exp Anim 1992; 41: 315-319.

16. Holt PG, Rose AH, Batty JE, Turner KJ. Introduction of adjuvant-independent IgE responses in inbred mice. Int Arch Allergy Appl Immunol 1981; 65: 42-50.

17. Sagai M, Saito H, Ichinose T, Kodama M, Mori Y. Biological effects of diesel exhaust particles (DEP). I. In vitro production of superoxide and in vivo toxicity in mice. Free Radic Biol Med 1993; 14: 37-47.

18. Sakaguchi M, Inoue S, Miyazawa H, Tamura S. Measurement of antigen specific mouse IgE by a fluorometric reverse (IgE-capture) ELISA. J Immunol Methods 1989; 116: 181-187.

19. Sorkness R, Clough JJ, Castleman WL, Lemanske RF. Virus-induced airway obstruction and parasympathetic hyperresponsiveness in adult rats. Am J Respir Crit Care Med 1994; 150: 28-34.

20. Durham SR, Lee TH, Cromwell O, et al. Immunologic studies in allergen-induced late-phase asthmatic reactions. J Allergy Clin Immunol 1984; 74: 49-60.

21. Rizzo MC, Arruda LK, Chapman MD, et al. IgG and IgE antibody responses to dust mite allergens among children with asthma in Brazil. Ann Allergy 1993; 71: 152-158.

22. Robinson DS, Ying S, Bentley AM, et al. Relationships among numbers of bronchoalveolar lavage cells expressing messenger ribonucleic acid for cytokines, asthma symptoms and airway methacholine responsiveness in atopic asthma. J Allergy Clin Immunol 1993; 92: 397-403.

23. Foster PS, Hogan SP, Ramsay AJ, Matthaei KI, Young IG. Interleukin 5 deficiency abolishes eosinophilia, airway hyperreactivity, and lung damage in a mouse asthma model. J Exp Med 1996; 183: 195-201.

24. Brusselle G, Kips J, Joos G, Bluethmann JH, Pauwels R. Allergen-induced airway inflammation and bronchial responsiveness in wild-type and interleukin-4-deficient mice. Am J Respir Cell Mol Biol 1995; 12: 254-259.

25. Gavett SH, O'Hearn DJ, Li X, Huang S, Finkelman FD, Wills-Karp M. Interleukin 12 inhibits antigen-induced airway hyperresponsiveness, inflammation, and Th2 cytokine expression in mice. J Exp Med 1995; 182: 1527-1536.

26. Renzi PM, Sapienza S, Waserman S, et al. Effect of interleukin-2 on the airway response to antigen in the rat. $\mathrm{Am}$ Rev Respir Dis 1992; 146: 163-169.

27. Enokihara H, Furusawa S, Nakakubo H. T cells from eosinophilic patients produce interleukin-5 with interleukin-2 stimulation. Blood 1989; 73: 1809-1813.

28. Snapper CM, Finkelman FD, Paul WE. Differential regulation of $\operatorname{IgG1}$ and $\operatorname{IgE}$ synthesis by interleukin 4. J Exp Med 1988; 167: 183-196.

29. Kaneko M, Swanson MC, Gleich GJ, Kita H. Aller-

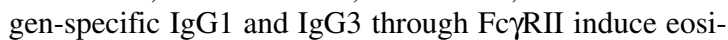
nophil degranulation. J Clin Invest 1995; 95: 2813-2821.

30. Hirata A, Motojima S, Fukuda T, Makino S. Damage to respiratory epitheium by guinea-pig eosinophils stimulated with IgG-coated Sepharose beads. Clin Exp Allergy 1996; 26: 848-858. 